\title{
Probiotic supplementation affects IGF-1 and leptin levels in Nile tilapia hepatopancreatic tissue
}

\author{
[Suplementação com probiótico afeta os níveis de IGF-1 e leptina no tecido \\ hepatopancreático de tilápias-do-nilo]

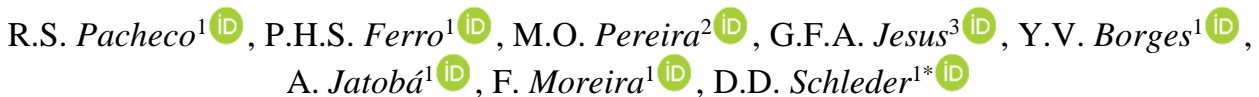 \\ ${ }^{1}$ Instituto Federal Catarinense, Campus Araquari, Araquari, SC, Brasil \\ ${ }^{2}$ GeneSeas, Santa Fé do Sul, SP, Brasil \\ ${ }^{3}$ Universidade Federal de Santa Catarina, Florianópolis, SC, Brasil
}

\begin{abstract}
This work aimed to assess the effect of the probiotic strain, Lactobacillus plantarum, on the levels of leptin, IGF-1 and their receptors on the hepatopancreatic tissues of Nile tilapia (Oreochromis niloticus) and then correlate fish growth performance and gut microbiological parameters. Fish juveniles $( \pm 23 \mathrm{~g})$ were reared in a recirculation system with constant aeration and temperature $\left(25^{\circ} \mathrm{C}\right)$. They were distributed into six polyethylene tanks (45L) and fed twice a day at $5 \%$ of the tank biomass with the respective diets: control (commercial diet without probiotic) and supplemented with $L$. plantarum inoculum $\left(1 \times 10^{8} \mathrm{CFU} \mathrm{mL}^{-1}\right)$, both in triplicate. After 30 days of feeding, L. plantarum-fed fishes showed greater weekly growth rate, final weight, and feed conversion rate, in addition to higher count of lactic-acid bacteria and lower count of pathogenic bacteria in the intestinal tract, when compared to the control group. The immunostaining intensity for IGF-1 and leptin hormones was lower after L. plantarum supplementation than in the control group, with no change in the level for receptors. This reduction could implicate important changes in fish metabolism and homeostasis.
\end{abstract}

Keywords: Oreochromis niloticus, Lactobacillus plantarum, growth, gut microbiology, hepatopancreas immunostaining

\section{RESUMO}

O presente trabalho teve como objetivo avaliar o efeito da cepa probiótica Lactobacillus plantarum sobre os níveis de leptina, IGF-1 e seus receptores no tecido hepatopancreático de tilápia-do-nilo (Oreochromis niloticus) e correlacionar com o desempenho zootécnico e os parâmetros microbiológicos intestinais dos peixes. Juvenis de tilápia-do-nilo $( \pm 23 g)$ foram distribuídos em seis tanques de polietileno (45L) conectados a um sistema de recirculação, com aeração e temperatura constantes $\left(25^{\circ} \mathrm{C}\right)$. Os peixes foram alimentados duas vezes ao dia, a 5\% da biomassa do tanque, com as respectivas dietas: controle (dieta comercial sem probiótico) e suplementada com L. plantarum ( $\left.1 \times 10^{8} \mathrm{UFC}_{\mathrm{mL}^{-1}}\right)$, ambas em triplicata. Após 30 dias de cultivo, os peixes alimentados com L. plantarum apresentaram maiores ganho de peso semanal, peso final e conversão alimentar, bem como maior contagem de bactérias ácido-láticas e menor contagem de bactérias patogênicas no trato intestinal das tilápias alimentadas com dieta probiótica, em comparação ao grupo controle. A intensidade da imunomarcação para os hormônios IGF-1 e leptina foi menor com a suplementação de L. plantarum do que no grupo controle, sem alterar os níveis de seus receptores. Essa redução pode implicar mudanças importantes no metabolismo e na homeostase dos peixes.

Palavras-chave: Oreochromis niloticus, Lactobacillus plantarum, crescimento, microbiologia intestinal, immunomarcação

*Corresponding author: delano.schleder@ifc.edu.br

Submitted: February 12, 2021. Accepted: June 19, 2021. 


\section{INTRODUCTION}

Nile tilapia (Oreochromis niloticus) is the third most cultivated fish species in the world, with 4.52 million tons produced in 2018, just behind the grass carp, Ctenopharyngodon idella (5.70 million tons), and silver carp, Hypophthalmichthys molitrix (4.79 million tons) (The State..., 2020). Brazil is the fourth largest tilapia producer in the world, accounting for $57 \%$ of national fish farming (432,149 tons in 2019) (Anuário..., 2020).

However, tilapia farming suffers from the emergence and spread of diseases, especially parasitic and bacterial diseases (Jatobá et al., 2016; Arguedas et al., 2017). In this context, the use of the probiotic strain Lactobacillus plantarum has shown potential for application in tilapia farming. This can be attributed to its high capacity to colonize the intestinal tract, inhibit pathogenic bacteria, and improve the nonspecific response of the tilapia immune system (Dotta et al., 2011; Jatobá et al., 2011).

Several studies have reported on the factors that regulate the metabolism and the immune response of vertebrates, as well as the effects of probiotics (Dar et al., 2018; Fabersani et al., 2017). Probiotics are related to the secretion of several hormones and signaling molecules such as neuropeptide Y (NPY), leptin, insulin, growth hormone (GH), and the cytokines TNF-a, IL6, and IL-1b (Bagarolli et al., 2017; Procaccini et al., 2017).

Leptin is a non-glycosylated peptide hormone belonging to class 1 of the cytokine superfamily that exerts pleiotropic function. It is responsible for reducing appetite and increasing energy expenditure through action on the hypothalamus, in addition to modulating the metabolism and immune system (Boguszewski et al., 2010). In fish, leptin is synthesized mainly in the liver, brain, and adipose tissue (Procaccini et al., 2017; Dar et al., 2018). The IGFs (insulin-like growth factors) are produced in different tissues and can mediate growth, inhibit lipolysis, increase glucose oxidation in adipose tissue, stimulate the transport of glucose and amino acids to the muscle and increase the synthesis of proteins by different mechanisms (De Palo et al., 2001; Roith, 2003).
The physiological roles of the hormones IGF-1 and leptin are related to the very physiological aspects affected by probiotics. Accordingly, the beneficial effects of $L$. plantarum supplementation on fish growth and physiological homeostasis reported in the literature could, at least in part, be associated with the regulation of IGF-1 and leptin levels in fish tissues. Therefore, the present work aimed to assess the effect of the probiotic strain L. plantarum on the levels of leptin, IGF-1 and their receptors in the hepatopancreatic tissues of Nile tilapia ( $O$. niloticus) growth, as well as correlate growth performance and gut microbiological parameters.

\section{MATERIALS AND METHODS}

Fish management followed protocol n ${ }^{\circ} 202 / 2017$ approved by the Ethics Animal Committee of the Instituto Federal Catarinense, Câmpus Araquari/IFCCA (26 22' 13" S, 48 43' 24" W). Nile tilapia fingerlings were obtained through natural reproduction and kept in four ponds $(10,000 \mathrm{~L})$. They were initially fed a commercial feed with $40 \%$ crude protein $\left(\mathrm{GUABI}^{\circledR}\right)$ for four weeks. After reaching 8-10g, they were fed a $32 \%$ crude protein feed $\left(\mathrm{GUABI}^{\circledR}\right)$ for three weeks, and then were transferred to the experimental units.

The experiment was carried out using a water recirculation system with physical and biological filter, and ultraviolet (UV) light for water sterilization. The filters were pre-matured by adding the $32 \%$ crude protein feed in tank water for 10 days. To confirm the nitrification process in the biological filter, water nitrate analysis was done at the beginning and at the end of the experiment (initial nitrate: $0.09 \pm 0.01$, final nitrate: $4.88 \pm 0.01 \mathrm{mg} \mathrm{L}^{-1} \mathrm{~N}-\mathrm{NO}_{3}$ ). Throughout the experiment, the temperature and dissolved oxygen (Oximeter YSI, Pro 20), pH (Bel W3b $\mathrm{pH}$ ), and total ammonia (TAN) were assessed daily according to Strickland and Parsons (1984) and APHA ((Standard..., 1995). All parameters were maintained at appropriate levels for the Nile tilapia culture: dissolved oxygen $4.35 \pm 0.23 \mathrm{mg} \mathrm{L}$ 1 , temperature $25.43 \pm 0.02^{\circ} \mathrm{C}, \mathrm{pH} 7.25 \pm 0.15$, and ammonia $0.02 \pm 0.01 \mathrm{mg} \mathrm{L}^{-1} \mathrm{~N}_{-} \mathrm{NH}_{3}-4$.

Prior to the experiment, a gradual acclimatization of the animals to the water of the experimental tanks was conducted for 50 minutes. Then, 48 tilapia juveniles were transferred to six polyethylene tanks with a capacity of $46 \mathrm{~L}$, 
totaling eight animals with $23.16 \pm 0.50 \mathrm{~g}$ per tank (total biomass of tank $185.35 \pm 4.03 \mathrm{~g}$ ). The experimental units were randomly divided into two treatments in triplicate: fish fed L. plantarumsupplemented diet (probiotic) and fish fed a diet without supplementation (control). The base diet used was a commercial feed with $32 \%$ crude protein from GUABI ${ }^{\circledR}$. The fish were acclimated for seven days and then reared for 30 days for the growth experiment. During both periods, the animals were fed twice a day (8:00 a.m. and 5:00 p.m.) at $4.5 \%$ of the biomass with the respective treatment diets.

The bacterial strain L. plantarum used in the experiment was first isolated by Jatobá et al. (2008) and maintained in the strain bank at the Aquaculture Laboratory of IFCCA. Experimental diets were prepared according to the protocols established by Jatobá et al. (2008). The probiotic diets received $10 \%$ of inoculum containing $L$. plantarum in culture medium at the concentration of $1 \times 10^{8}$ colony forming units (CFU) $\mathrm{mL}^{-1}$. Control diets, however, received only the sterile culture medium in the same proportion. After homogeneous mixing of the inoculum in the diets, they were oven dried at $37^{\circ} \mathrm{C}$ for about two hours. At the end, all diets were stored at $4^{\circ} \mathrm{C}$.

After the rearing period, the animals remained fasting for 12 hours for the final biometry and for sampling the intestinal tract and liver. All fish from each tank were collected, counted, and weighed. Growth performance parameters were determined as follows:

Weekly weight gain $=($ final weight - initial weight)/ number of weeks;

Feed conversion ratio $(\mathrm{FCR})=$ feed intake (amount of feed off ered to each tank throughout the experiment) / weight gain;

Survival (\%): (Final count x 100) / Initial count.

For intestinal tract and liver sampling, the animals were anesthetized with Eugenol $\left(50 \mathrm{mg} \mathrm{L}^{-1}\right)$ and euthanized by transection of the spinal cord. Segments (mid- and hindgut) of the intestinal tract $( \pm 20 \mathrm{~cm})$ were collected from two animals per experimental unit to form a pool. Then they were weighted, macerated and serially diluted (factor $1: 9)$ in a sterile saline solution $(0.65 \%)$, all in sterile environment and using sterile tools.
Dilutions were seeded on MRS agar medium (deMan, Rogosa and Sharpe), and incubated for $48 \mathrm{~h}$ at $35^{\circ} \mathrm{C}$, for total counts (CFU) of lactic acid bacteria. The colonies that had the highest concentrations, in both treatments, were compared with the probiotic strain through Gram staining. For potentially pathogenic bacteria counting, specifically Vibrio spp., the dilutions were seeded in TCBS (Thiosulfate-Citrate-BileSaccharose Agar) medium and incubated for $24 \mathrm{~h}$ at $30^{\circ} \mathrm{C}$, as described by Jatobá et al. (2008).

Liver samples were collected from two fish per treatment and immediately fixed in $10 \%$ formalinbuffered solution for histological processing and immunohistochemistry analysis at the Animal Physiology Laboratory of IFCCA. Primary polyclonal antibodies were directed against the proteins of interest (leptin, IGF-I, and their receptors): LEP antibody (anti-leptin) (A-20); LEPR antibody (anti-leptin receptor) (pAb M-18); Anti-IGF- 1(H-70), and anti-IGF- $1 \beta$ receptor (C20) (Santa Cruz Biotechnology, CA, USA). Sections $(4 \mu \mathrm{m})$ of liver tissues were made on microtome (RM2245, Leica Biosystems, San Diego, CA, USA) and adhered on slides preimpregnated with $3 \%$ organosilane solution (Sigma-Aldrich Chemical Company, St. Louis, MO, USA) in alcohol, according to Moreira et al. (2013).

Endogenous peroxidase blockade was previously performed using a commercial kit (Spring Bioscence, Pleasanton, USA) and antigenic recovery in citrate solution under moist heat conditions. To block non-specific markers, the blocking solution for nonspecific protein markers (Spring Bioscence, Pleasanton, CA, USA) was dropped onto the slides, and after addition of the primary antibody the slides were incubated overnight in a humid chamber at $4^{\circ} \mathrm{C}$.

After washing with PBS, the secondary antibodies were dropped onto the slides using the $\mathrm{HRP}^{\circledR}$ Polyvalent Reveal Kit (Spring Bioscence, Pleasanton, CA, USA), and then incubated at room temperature in a humid chamber. The reaction was revealed by the addition of diaminobenzidine peroxidase solution (DABK3468, DAKO Corporation, Carpinteria, CA, USA), stained with Mayer's Hematoxylin (Merck, Darmstadt, Germany) and covered with coverslips using synthetic resin (Sigma-Aldrich ${ }^{\circledR}$ Chemical Company, St. Louis, MO, USA). 
The slides were observed under a light field microscope and the intensity of the immunostaining of the proteins and their receptors of interest were observed in the hepatopancreatic acinus cytoplasm, with an average of 10 acini per slide, totaling 60 acini per treatment. Classification was based on the mode value observed in each recorded area (Moreira et $a l ., 2013)$, using the 64 bit-Histogram application with an Image $\mathbf{J}^{\circledR}$ software scale, for which 0 is the most intense and 255 the least intensity.

For statistical analysis, the data were previously submitted to Bartlett's analysis to verify the homogeneity of data variance. When the homogeneity was confirmed, a t-test for means separation was performed using $5 \%$ of significance. All analyses were performed using Statistica $13^{\circledR}$.

\section{RESULTS AND DISCUSSION}

Tilapia juveniles fed the diet supplemented with probiotic bacteria had a better weekly weight gain, final weight, and feed conversion compared to the control group $(p<0.05)$. However, no significant difference was observed for survival (Table 1).

Table 1. Growth performance and immunostaining of leptin and IGF-1 and their respective receptors (Rec. IGF-1 and Rec. Leptin) in the hepatopancreatic acini of Nile tilapia after 30 days of feeding diets supplemented with probiotic strain Lactobacillus plantarum and without supplementation (control)

\begin{tabular}{lccc}
\hline \multirow{2}{*}{ Growth parameters } & \multicolumn{2}{c}{ Treatment } & $p$ \\
\cline { 2 - 3 } & Control & Probiotic & 0.0230 \\
Weekly weight gain $(\mathrm{g})$ & $3.43 \pm 0.08$ & $5.84 \pm 0.64$ & 0.0347 \\
Initial weight $(\mathrm{g})$ & $23.55 \pm 0.32$ & $22.77 \pm 0.27$ & 0.0325 \\
Final weight $(\mathrm{g})$ & $38.25 \pm 0.22$ & $47.75 \pm 3.07$ & 1.000 \\
Survival (\%) & $85.70 \pm 11.36$ & $85.71 \pm 0.89$ & 0.0385 \\
Feed conversion ratio & $2.22 \pm 0.24$ & $1.58 \pm 0.04$ & \\
\hline Immunostaining markers & & & 0.0001 \\
\hline IGF 1 & $68.20 \pm 11.06$ & $82.10 \pm 10.78$ & 0.0155 \\
Leptin & $80.90 \pm 11.54$ & $87.10 \pm 11.86$ & 0.1750 \\
Rec. IGF - 1 & $85.43 \pm 18.83$ & $80.10 \pm 10.70$ & 0.0907 \\
Rec. Leptin & $86.00 \pm 6.81$ & $89.69 \pm 9.26$ & \\
\hline
\end{tabular}

Data presented as means \pm standard deviation.

${ }^{1} 255$ the least intense marking and 0 the most intense marking.

According to microbiological analyses, lactic acid bacteria count $(p<0.05)$ increased in the intestinal tract of tilapia fed the supplemented diet (4.60 $\pm 0.89 \log _{10}$ UFC $\mathrm{mL}^{-1}$ ), when compared to the control group $(1.80 \pm 0.26)$, most likely owing to the L. plantarum supplementation in this diet. Moreover, probiotic supplementation reduced $(p$ $<0.05)$ the count of potentially pathogenic bacteria, in particular Vibrio spp., in the gut of Nile tilapia $(4.80 \pm 0.80)$, when compared to the control group (6.20 \pm 0.60$)$ (Fig. 1).

Considering the thermal level used in the present work $\left(25.43 \pm 0.02^{\circ} \mathrm{C}\right)$, Nile tilapia juveniles showed adequate growth performance (Nobrega et al., 2019). In addition, L. plantarum showed a clear probiotic effect on Nile tilapia gut, reducing pathogenic bacteria count and improving growth performance. These data corroborate the positive effects of this probiotic strain on Nile tilapia physiology and growth performance, as extensively reported in the literature (Jatobá et al., 2008, 2011; Dotta et al., 2011).

The results of immunostaining of hepatopancreatic acini demonstrated the reduced intensity of IGF-1 and leptin markers $(p<0.05)$ in the probiotic-supplemented group compared to that in the control group. However, no difference ( $p>0.05$ ) was seen for the immunostaining of their respective receptors in the evaluated groups (Table 1; Fig. 2). 


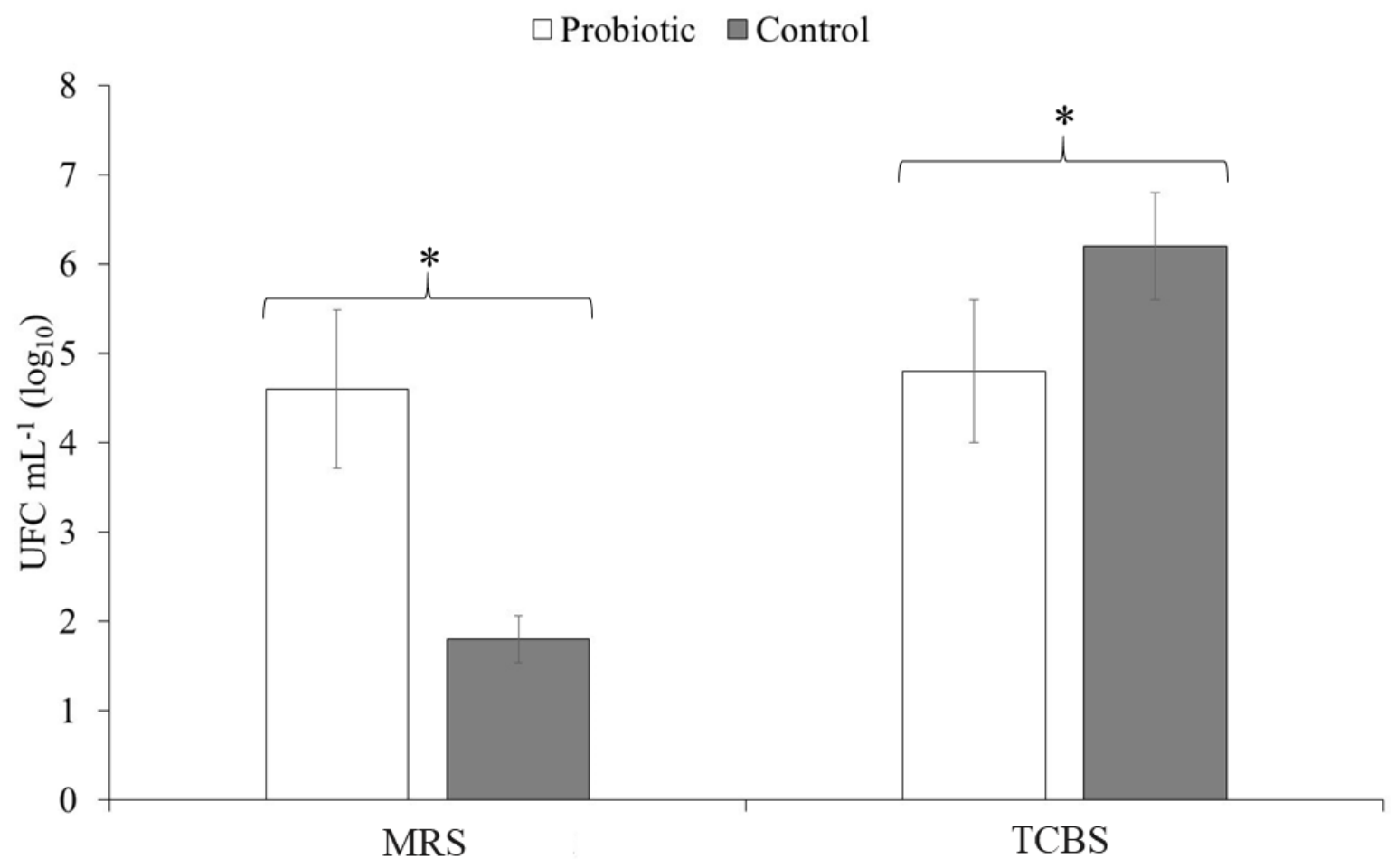

Figure 1. Colony Forming Unit (CFU) $\mathrm{mL}^{-1}$ count of lactic acid bacteria (MRS medium) and of Vibrio spp. and other potentially pathogenic bacteria (TCBS medium) of the intestinal tract of Nile tilapia after 30 days of feeding using diets without (control diet) and with supplementation of the probiotic strain L. plantarum.
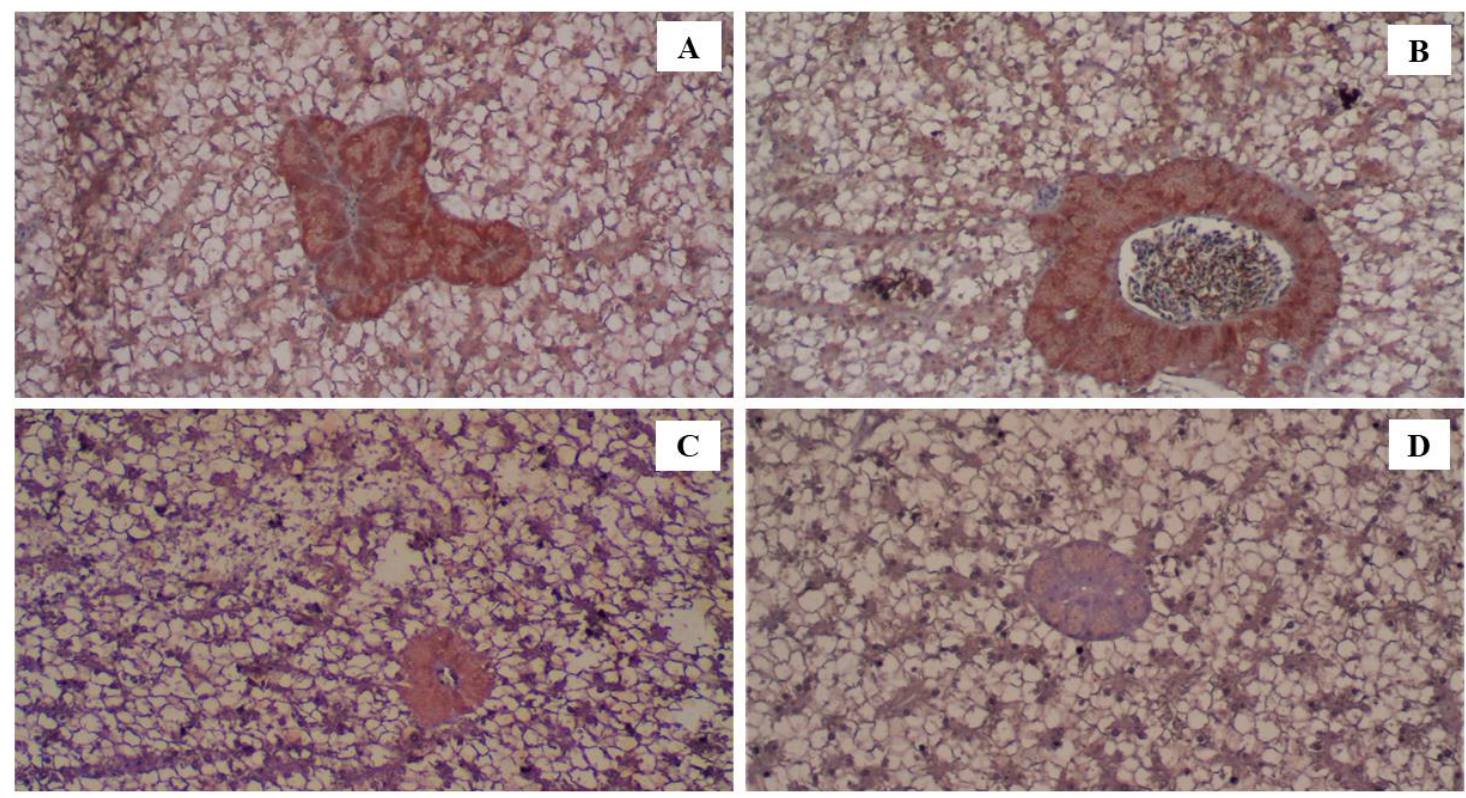

Figure 2. Photomicrography of hepatic tissue containing pancreatic acini of Nile tilapia fed diets without (control diet) and with supplementation of the probiotic strain L. plantarum. A and C represent the control group with the greatest intensity of immunostaining for IGF-1 and leptin, respectively. B and D represent the treatment with L. plantarum with a lower intensity of immunostaining for IGF-1 and leptin, respectively. 
Won and Borski (2013) and Carnevali et al. (2017) reported that the administration of probiotics significantly decreases the secretion of the neuropeptide Y (NPY), which controls the circulating levels of leptin and form a network of signals responsible for the control of reproductive processes and food intake. The decrease in leptin levels during fasting time is associated with the increase of the motivation to seek food, as well as the reward sensation when the animal ingests food, in addition to inducing anorexic neurocircuits involved in reducing the catabolism of sugars and lipids (Münzberg et al., 2015).

The reduction of leptin and IGF-1 immunostaining in the $L$. plantarum supplemented group, may have resulted from the combined action of the probiotic and the fasting period before sampling, which lasted approximately 12 hours. In the mandarin fish, Siniperca chuatsi, a brief fasting from one to six hours resulted in a significant reduction of leptin expression (sLEP-B) in different tissues (Yuan et al., 2016). Moreover, prolonged fasting, e.g., from one to seven days, also decreased leptin expression, the activity of digestive enzymes, and the levels of glucose, fatty acids and glycogen in the body, as well as the activity of enzymes associated with glycolysis and lipolysis, in rohu (Labeo rohita) fingerlings (Dar et al., 2018).

Therefore, the decrease in leptin observed in $L$. plantarum-fed tilapia may have caused an increased motivation to obtain food and the corresponding sensation of reward for ingesting it. In addition to changes in the metabolism and energy reserves, it could justify the increased weight gain verified in the present work, and in previous studies with the same strain (Jatobá et al., 2008; Jatobá et al., 2011).

Moreover, the modulation of leptin gene expression is not only related to food intake, but also to the action of different inflammatory mediators. According to Procaccini et al. (2017), leptin levels, in general terms, are inversely correlated with glucocorticoid hormones, and its secretion increases during inflammatory, infectious or septicemic processes, through the action of different cytokines, such as TNF- $\alpha$, IL6 and IL-1 $\beta$, as well as activation by lipopolysaccharide (LPS) from Gram negative bacteria.
Higher levels of leptin and IGF-1 increase the metabolic rate and the production of reactive oxygen species, compromising the gene expression of antioxidant defense proteins in liver and muscle tissues, in turn causing oxidative stress (Rosa et al., 2008; Schroyen et al., 2012). On the other hand, the reduction of leptin levels induces an anti-inflammatory and antioxidant state (Procaccini et al., 2017).

In humans, probiotic administration in patients with non-alcoholic fatty liver disease (NAFLD) caused the reduction of leptin with concomitant beneficial effects on glycemic parameters and the control of insulinemia and serum leptin (Behrouz et al., 2017). Correspondingly, Takemura et al. (2010) administered L. plantarum as a probiotic in obese rats, and observed a decrease in cholesterol, leptin, and adipose tissue cell size. Mcmullen et al. (2006); Rouhani et al. (2018) reported that strains of Lactobacillus and Bifidobacterium may exert some significant effects on the concentration of leptin and adiponectin circulation, decreasing enterohepatic circulation of conjugated hormones in the intestine by means of hydrolysis. From this perspective, the probiotic L. plantarum may have influenced leptin and IGF- 1 levels in the liver, which may have triggered important metabolic changes, and contributed to better growth performance of the animals.

In fact, L. plantarum has been associated with positive effects on fish physiology, immune response and growth performance. Hamdan et al. (2016) fed Nile tilapias diets containing different levels of $L$. plantarum, and observed an improvement of fish immune response, disease resistance, hematological parameters, gut morpho-physiology and growth performance. All these physiological mechanisms are influenced by different hormones and signaling molecules, including leptin and IGF-1.

The regulation of catabolic and anabolic mechanisms is influenced by the interaction among growth hormone (GH), IGF-I, leptin and their receptors. Leptin is an important stimulator of GH and IGF-1 production in teleost and through the feedback mechanism. Leptin and IGF-1 are involved in enhancing the synthesis of proinflammatory cytokines and the growth of tilapias and other fish species (Fuentes et al., 2012, Trombley et al., 2012; Douros et al., 2017). 
Therefore, our present results suggest that the reduction of leptin and IGF-1, as shown in the immunostained hepatopancreatic tissue of $L$. plantarum-fed tilapia during the fasting period may be associated with higher stimulus to seek food, as well as the increase of anti-inflammatory and antioxidant defenses to the detriment of growth and reproduction (Carnevali et al., 2017). To the best of our knowledge, this is the first study reporting the effect of probiotic supplementation on these hormones in Nile tilapia hepatopancreatic tissue. However, further studies should be conducted to evaluate the influence of L. plantarum on the levels of these proteins in newly fed tilapia (without fasting) to further bring to light the effects of this strain on physiology and growth performance.

\section{CONCLUSIONS}

L. plantarum supplementation improved growth performance and reduced potentially pathogenic bacteria count in the intestinal tract of Nile tilapia juveniles. In addition, it decreased the levels of leptin and IGF- 1 in the hepatopancreatic acini during $12 \mathrm{~h}$ fasting, but it did not affect the levels of their receptors. Therefore, the results of the present work could shed light on the mechanisms by which $L$. plantarum affects Nile tilapia physiology and growth performance.

\section{AKNOWLEDGMENTS}

The authors thank National Council of Scientific and Technologic Development (CNPq) for providing an initiation grant to the second author, and to Guabi Nutrition and Animal Health S.A. for the donation of the rations. Finally, to Andressa Vieira for helping the first author with the microbiological analysis.

\section{REFERENCES}

ANUÁRIO peixe BR da piscicultura. São Paulo: Associação Brasileira da Piscicultura, 2020. Available

https://www.peixebr.com.br/Anuario2020/Anuari oPeixeBR2020.pdf?. Accessed in: 10 Jun. 2020.

ARGUEDAS, D.; ORTEGA, S.; MARTÍNEZ, S.; ASTROZA, A. Parasites of Nile tilapia larvae Oreochromis niloticus (Pisces: Cichlidae) in concrete ponds in Guanacaste, Northern Costa Rica. Cuad. Invest., v.9, p.313-319, 2017.
BAGAROLLI, R.A.; TOBAR, N.; OLIVEIRA, A.G. et al. Probiotics modulate gut microbiota and improve insulin sensitivity in DIO mice. J. Nutr. Biochem., v.50, p.16-25, 2017.

BEHROUZ, V.; JAZAYERI, S.; ARYAEIAN, N.; ZAHEDI, M.J.; HOSSEINI, F. Effects of probiotic and prebiotic supplementation on leptin, adiponectin, and glycemic parameters in nonalcoholic fatty liver disease: A randomized clinical trial. Middle East J. Dig. Dis., v.9, p,150157, 2017.

BOGUSZEWSKI, C.L.; PAZ-FILHO, G.; VELLOSO, L.A. Neuroendocrine body weight regulation: integration between fat tissue, gastrointestinal tract, and the brain. Endokrynol. Pol., v.61, p.194-206, 2010.

CARNEVALI, O.; MARADONNA, F.; GIOACCHINI, G. Integrated control of fish metabolism, wellbeing and reproduction: The role of probiotic. Aquaculture, v.472, p.144-155, 2017.

DAR, S.A.; SRIVASTAVA, P.P.; VARGHESEA, T. et al. Eff ects of starvation and refeeding on expression of ghrelin and leptin gene with variations in metabolic parameters in Labeo rohita fingerlings. Aquaculture, v.484, p.219-227, 2018.

DE PALO, E.F.; BASSANELLO, M.; LACERIN, F. et al. GH/IGF system, cirrhosis and liver transplantation. Clin. Chim. Acta, v.310, p.31-37, 2001.

DOTTA, G.; MOURIÑO, J.L.P.; JATOBÁ, A. et al. Acute inflammatory response in nile tilapia fed probiotic Lactobacillus plantarum in the diet. Acta Sci. Biol. Sci., v.33, p.239-246, 2011.

DOUROS, J.D.; BALTZEGAR, D.A.; MANKIEWICZ, J. et al. Control of leptin by metabolic stat and its regulatory interactions with pituitary growth hormone and hepatic growth hormone receptors and insulin like growth factors in tilápia (Oreochromis mossambicus). Gen.Comp. Endocrinol., v.240, p.227-237, 2017.

FABERSANI, E.; ABEIJON-MUKDSI, M.C.; ROSS, R. et al. Specific strains of lactic acid bacteria differentially modulate the profile of adipokines in vitro. Front. Immunol., v.8, p,1-16, 2017. 
FUENTES, E.N.; KLING, P.; EINARSDOTTIR, I.E. et al. Plasma leptin and growth hormone levels in the fine flounder (Paralichthys adspersus) increase gradually during fasting and decline rapidly after refeeding. Gen.Comp. Endocrinol., v.177, p.120-127, 2012.

HAMDAN, A.M.; EL-SAYED, A.F.M.; MAHMOUD, M.M. Effects of a novel marine probiotic, Lactobacillus plantarum $\mathrm{AH} 78$, on growth performance and immune response of Nile tilapia (Oreochromis niloticus). J. Appl. Microbiol., v,120, p.1061-1073, 2016.

JATOBÁ, A.; KLIPP, S.P.; HOPPE, R. First report of Francisella noatunensis subspecies orientalis in southern of Brazil-Case Report. Acta Vet. Bras., v.10, p.172-176, 2016.

JATOBÁ, A.; VIEIRA, F.N.; BUGLIONE NETO, C.; SILVA, B.C. et al. Lactic-acid bacteria isolated from the intestinal tract of Nile tilapia utilized as probiotic. Pesqui. Agropecu. Bras., v.43, p.1201-1207, 2008.

JATOBÁ, A.; NASCIMENTO VIEIRA, F.; BUGLIONE-NETO, C.C. et al. Diet supplemented with probiotic for Nile tilapia in polyculture system with marine shrimp. Fish Physiol. Biochem., v.37, p.725-732, 2011.

MCMULLEN, M.H.; HAMILTON-REEVES, J.M.; BONORDEN, M.J.L. et al. Consumption of Lactobacillus acidophilus and Bifidobacterium longum does not alter phytoestrogen metabolism and plasma hormones in men: a pilot study. $J$. Altern. Compl. Med., v.12, p.887-894, 2006.

MOREIRA, F.; CORCINI, C.D.; MONDADORI, R.G. et al. Leptin and mitogen-activited protein kinase (MAPK) in oocytes of sows and gilts. Anim. Reprod. Sci., v.139, p.89-94, 2013.

MÜNZBERG, H.; MORRISON, C.D. Structure production and signaling of leptin. Metabolism, v.64, p.13-23, 2015.

NOBREGA, R.O.; BATISTA, R.O.; CORRÊA, C.F. et al. Dietary supplementation of Aurantiochytrium sp. meal, a docosahexaenoicacid source, promotes growth of Nile tilapia at a suboptimal low temperature. Aquaculture, v.507, p.500-509, 2019.

PROCACCINI, C.; ROCCA, C.L.; CARBONE, F. et al. Leptin as immune mediator: Interaction between neuroendocrine and immune system. Dev. Comp. Immunol., v.66, p.120-129, 2017.
ROITH, D.L. The insulin-like growth factor system. Exp. Diabetes Res., v.4, p.205-212, 2003.

ROUHANI, M.H.; HADI, A.; GHAEDI, E. et al. Do probiotics, prebiotics and synbiotics affect adiponectin and leptina in adults? A systematic review and meta-analysis of clinical trials. Clin. Nutr., v.30, p.1-7, 2018.

ROSA, C.E.; FIGUEIREDO, M.A.; LANES, C.F.C. et al. F. Metabolic rate and reactive oxygen species production in different genotypes of GHtransgenic zebrafish. Comp. Biochem. Physiol. Part B Biochem. Mol. Biol., v.149, p.209-214, 2008.

STANDARD methods for the examination of water and wastewater. 19.ed. Baltimore: APHA, 1995. 1100p.

STRICKLAND, J.D.; PARSONS, T.R. (Eds.). A practical handbook of seawater analysis. Canada: Unipub, 1984. 310p. (Bulletin 167).

SCHROYEN, B.; GUIMARÃES, E.L.; DOLLÉ, L. et al. Leptin-mediated reactive oxygen species production does not significantly affect primary mouse hepatocyte functions in vitro. Eur. J. Gastroenterol. Hepatol., v.24, p.1370-1380, 2012.

THE STATE of the world fisheries and aquaculture. Rome: FAO, 2020. Available in: http://www.fao.org/3/ca9229en/ca9229en.pdf. Accessed in: 15 Oct. 2020.

TROMBLEY, S.; MAUGARS, G.; KLING, P.; BJÖRNSSON, B.T.; SCHMITZ, M. Effects of long-term restricted feeding on plasma leptin, hepatic leptin expression and leptin receptor expression in juvenile Atlantic salmon (Salmo salar L.). Gen. Comp. Endocrinol., v.175, p.9299, 2012.

TAKEMURA, N.; OKUBO, T.; SONOYAMA, K. Lactobacillus plantarum strain No. 14 reduces adipocyte size in mice fed high-fat diet. Exp. Biol. Med., v.235, p.849-856, 2010.

WON, E.T.; BORSKI, R.J. Endocrine regulation of compensatory growth in fish. Front. Endocrinol., v.4, p.1-13, 2013.

YUAN, X.; LI, A.; LIANG, X.F. et al. Leptin expression. in mandarin fish Siniperca chuatsi (Basilewsky): Regulation by post prandial and short-term fasting treatment. Comp. Biochem. Physiol. Part A Mol. Integr. Physiol., v.194, p.818, 2016. 